Work of Committees.

New committees have been formed for dealing with the conservation of natural sources of energy, and to consider the question of technical education and its position in regard to universities. In addition to these, there are committees dealing with education, inexpensive instruments in science teaching, agriculture, synchronisation of clocks, naming and numbering of streets (executive committee), and the coordination of charitable effort.

The medical committee has been increased in numbers in order to take up specially the consideration of medical research. In its report this committee emphasises the very great importance of post-graduate medical study, and points out the very wide field and the great materials for such work which exist in London, and that owing to the absence of organised effort relatively little use is being made of this immense field. It is further considered that the ideal to be worked for is the establishment of a central medical school in connection with the London University, which should be devoted to post-graduate teaching and researche Such central school might be associated with all the London hospitals in connection with the London University for the purpose of post-graduate medical study, and should have affiliated to it other medical institutions and hospitals for the treatment of special types of disease (such as hospitals for epilepsy and diseases of the nervous systems, the Royal Ophthalmic Hospital at Moorfields, Brompton Hospital for Consumptives, \&c.). Professors appointed by the Central London University School would be deputed to work at any of the appointed institutions, where special facilities might exist for research and post-graduate teaching in the subject dealt with by each professor. The committee is strongly of the opinion that much greater facilities should be given for medical research than exist at the present time, and that large funds should be furnished from public and private sources for such purposes. One of the objects on which expenditure is urgently required is in the endowment by the Central London University School of arrangements for pathological research at the medical schools.

The committee on the conservation of natural sources of energy, of which Sir William Ramsay is chairman, has decided to draw up reports on ( $r$ coal, particularly in connection with its employment for sneiting and other industrial purposes; (2) internal-combustion engines and oil engines; (3) atomic and interatomic energy; (4) the availability and quantity of natural oil and natural gas; (5) the heat of the earth; (6) availability of water-power: (7) forestry; (8) carburisation of coal at high and low temperatures; (9) solar power.

\section{THE PROPOSED SCOTTISH NATIONAL} ANTARCTIC EXPEDITION OF I9I.

A LARGE and enthusiastic meeting, organised by A the Royal Scottish Geographical Society, was held in the Synod Hall, Edinburgh, on Thursday evening, March 17, to hear the plans of Dr. Bruce for his second Antarctic expedition. Prof. J. Geikie, F.R.S., president of the society, was in the chair, and was supported by a number of representatives of Scottish scientific bodies and others. The keynote of the meeting was that the aim of the expedition was to be throughout scientific. This was emphasised first of all by the chairman, who on that ground disclaimed the idea against which a needless protest had been put forth by the president of the Geographical Society of Berlin, that Antarctic exploration should be in any way reserved for any particular nation, and, in view of the immense field for scientific investigation in Antarctica, welcomed the friendly rivalry of all nations in carrying out that work.

Dr. Bruce then addressed the meeting, and before giving an account of his present plans, gave a brief sketch of the history of Antarćtic exploration, laying special stress on the part that Scotsmen had borne in that work since Weddell set sail from Leith in 1823. It is hoped that the expedition now planned will leave Scotland about May $x$, I9II, and reach
Buenos Aires about June 20 of that year. About ten days later it will sail for Cape Town, pursuing a zigzag course, for the most part, between the paralleis of $40^{\circ}$ and $50^{\circ} \mathrm{S}$., but including a visit to the Sandwich group in about $57^{\circ} \mathrm{S}$., as well as to Gough Island. The purpose of this navigation will be to supplement the bathymetrical survey of the South Atlantic Ocean begun by the Scotia in 1902-4, and it is not expected that Cape Town will be reached before September r. After refitting and coaling, the ship will sail once more for the Sandwich group, and thence to Coats Land, and seek for a place on or near that coast where it may be possible to land and erect a house, although from the experience of the previous expedition it is thought possible that it may be necessary to go so far east as Cape Ann in Enderby Land for that purpose. At some point in Coats Land, however, it is intended that a sledge-party of three, under the leadership of Dr. Bruce, shall land with the view of crossing to the Ross Sea by way of the South Pole. The ship, after landing a party of ten or twelve persons at whatever point they find suitable for the erection of a house, will proceed, by a route in as high a latitude as possible, to winter at Melbourne, taking soundings and carrying on deepsea research all the way.

In the following spring the ship will leave Melbourne and push southward to McMurdo Strait, Victoria Land, in order to send a sledge party to meet, and furnish with fresh supplies, the previously landed sledge-party under Dr. Bruce. It is expected that the two parties will meet near the Beardmore Glacier, and, after meeting, the combined party will proceed to the ship and sail for New Zealand. Further oceanographical work will afterwards be carried on between New Zealand and the Falkland Islands in as high a latitude as the winter season will permit, and in the following spring the ship will sail southwards to relieve the wintering party, which by that time will have been engaged for two years in surveying the coast-line of Antarctica east and west of the station, and in taking meteorological, magnetic, and other observations. The total cost of the expedition is estimated at about $50,000 l$. Dr. Bruce, it may be mentioned, is in cordial correspondence, not merely with Captain Scott, but also with the promoters of the German expedition, and there is good reason to hope that if funds are raised both for his and the German expedition, there will be no useless overlapping of work. As regards the McMurdo Strait, which Captain Scott has chosen for his special sphere of work, Dr. Bruce expressly announces that the Scottish expedition will make no special investigations in that region.

The meeting was then addressed by Dr. John Horne, F.R.S., director of the Geological Survey of Scotland, who, as representing the Royal Society of Edinburgh, first referred to the high value of the publications already issued giving the scientific results of Dr. Bruce's previous Antarctic expedition, including upwards of twenty papers published by the society he represented, and expressed the hope that the Government would see its way to furnish the necessary funds for the publication of the remaining results, which were eagerly looked for by all interested in Antarctic exploration in every part of the world. He stated that he was commissioned by the council of the society to give to Dr. Bruce's new scheme the most cordial recommendation to the Scottish public for financial assistance.

Prof. J. Graham Kerr, F.R.S., professor of zoology in the University of Glasgow, then spoke as representative of the Royal Philosophical Society of Glasgow, expressing that society's cordial sympathy with Dr. Bruce's project, and especially because they felt that they had in him a splendid example of the type of explorer who, while ready to take any adventures that came his way, recognised that his real object was to do honest scientific work. The Earl of Cassilis, representing the St. Andrew Society, dwelt 
more particularly on the contrast presented by the large grants that had been made by Government to other Antarctic expeditions, and the entire lack of recognition, so far, of the work of proved value that had been done by Dr. Bruce.

Prof. J. Cossar Ewart, F.R.S., professor of zoology in the University of Edinburgh, then commented on the zoological value of Dr. Bruce's expeditions, which had been the means of adding dozens of new species to scientific knowledge, and on that account gave his cordial support to the carrying out of this second Scottish Antarctic Expedition. In an eloquent speech Prof. D'Arcy W. Thompson, C.B., of the Scottish Fishery Board, professor of zoology in University College, Dundee, expressed warm appreciation of the work that Dr. Bruce had already done in his previous expeditions. Mr. Chisholm, lecturer on geography, Edinburgh University, recommended Dr. Bruce's plans to the support of the meeting, among other grounds, on account of the fact that Dr. Bruce had shown his qualifications as a leader by the attachment and devotion which he inspired in his followers, and this point was immediately enforced by Dr. R. N. Rudmose Brown, lecturer on geography in the University of Sheffield, who had accompanied him in expedition after expedition.

At the close of the meeting, on the motion of $\mathrm{Mr}$. W. G. Burn-Murdoch, a resolution asking the meeting, as a representative Scottish gathering, to express their hearty desire to have Dr. Bruce's plans carried out, was unanimously approved. It should be added that, while the opinion that it was the duty of the Government to contribute to the publication of the results of the Scotia expedition was very freely expressed at the meeting, the appeal for funds to carry out the present projected expedition is not made, in the first instance at least, to the Government, but to "the enthusiasm and patriotism of Scots at home and abroad."

\section{PROF. J. CAMPBELL BROWN.}

$A S$ recorded with regret last week, Prof. James Campbell Brown, professor of general chemistry at the University of Liverpool, died very suddenly from heart failure on Monday, March i4. Prof. Campbell Brown, who was the son of the late Mr. George Brown, a chemical manufacturer with a business in London, was born in Aberdeenshire in 1843. He studied at the University of Aberdeen, and afterwards at the Royal College of Chemistry and the Royal School of Mines, London. He was a D.Sc. of London University, and LL.D. (honoris causa) of the University of Aberdeen. His connection with Liverpool began in 1867 , when he was appointed lecturer in chemistry and toxicology at the Royal Infirmary School of Medicine. He became public analyst for Liverpool in 1872 , for Cheshire and the Isle of Man in 1873 , and for Lancashire in 1875 . In 1877 , being then chairman of the Royal Infirmary School of Medicine, he took a prominent part in the movement for the foundation of a university college in Liverpool, and from 1878 to 1884 was one of the secretaries of the special committee which afterwards became the council of the new college. Prof. Campbell Brown may, therefore, rightly be said to have been one of the prominent founders of the present University of Liverpool. In $188 \mathrm{x}$ he was appointed to the chair of chemistry endowed by Mr. Grant, of Rock Ferry. When death overtook him he was still the active occupant of this chair.

For more than forty years Prof. Campbell Brown exercised an important and beneficial influence on higher education, and especially higher scientific education, in this country. In Liverpool in particular he developed a flourishing department of chemistry, and was very successful in enlisting the sympathy and obtaining the aid of the chemical manufacturers of Lancashire and Cheshire. As a public analyst of experience and repute he did much for the improvement of our methods of suppressing the falsification and adulteration of foods and drugs.

In 1874 he published a report on the chemistry of tea cultivation in India, and made important recommendations which proved of great value to that industry.

$\mathrm{He}$ contributed a very considerable number of papers to the scientific journals, and was awarded two gold medals by the Franco-British Exhibition. In this connection his excellent work on the latent heats of evaporation of liquids deserves special mention. Quite recently he contributed a paper to the Chemical Society dealing with double and triple ferricyanides.

In rgo8 he was elected a vice-president of the Chemical Society. A man of genial, kindly, and unselfish nature, his heart was entirely in the work to which his life was devoted. He lived to see his labours crowned with a well-deserved success. The University of Liverpool owes him a debt of gratitude which few can appraise, and it stands to-day a memorial of his wisdom and foresight, his marvellous power of organisation, and his profound belief in the value of the investigation and dissemination of knowledge and truth.

F. G. D.

\section{NOTES.}

Sir William Ramsay, K.C.B., has been nominated "Membre d'Honneur"-honorary member-of the Chemical Society of France.

Sir Thomas Barlow, F.R.S., has been elected president of the Royal College of Physicians, London, in succession to Sir Richard D. Powell.

The Aldred lecture of the Royal Society of Arts will be delivered by Prof. H. H. Turner, F.R.S., on Wednesday, May 4. The title of the lecture is "Halley and his Comet."

THE death is announced, in his seventy-second year, of Dr. Otto Hermes, founder of the Berlin Aquarium. Dr. Hermes was appointed director of the aquarium in $187 \mathrm{I}$, and was known by his writings on zoological subjects.

AMONG the latest developments of Germany's airship movement we notice the fund raised by Prince Henry of Prussia for the building of a dock at Hamburg capable of housing at least two Zeppclins. Of the 50,00ol. required, $20,000 l$. was raised almost immediately.

A young horn of Cervus megaceros has been dug up recently from a depth of 2 or 3 feet below the surface of Martin Mere, near Southport, in Lancashire. It is the property of the Rev. Mr. Bulpit of that town, by whom the specimen has been submitted for determination to the director of the Liverpool Museums.

THE following awards of the Royal medals and other honours have been made by the council of the Royal Geographical Society:-Royal gold medals: founder's medal, Colonel H. H. Godwin Austen, C.M.G., F.R.S. ; patron's medal, Dr. W. S. Bruce; Murchison grant, Dr. Carl Skottsberg; Gill memorial, Mr. D. Carruthers, for his journey in north central Arabia; Cuthbert Peek grant, Lieut. C. E. Fishbourne, R.E.; Back bequest, Mr. H. Vischer. A special medal has been awarded to RearAdmiral Peary for his attainment of the North Pole. 